\title{
A PELE QUE HABITAMOS: AS (AUTO)NARRATIVAS DE RUTH, ZEZÉ E LÁZARO
}

\section{THE SKIN WE INHABIT: THE (SELF) NARRATIVES OF RUTH, ZEZÉ, AND LÁZARO}

\author{
Samanta Samira Nogueira Rodrigues ${ }^{1}$ \\ Universidade do Estado do Rio de Janeiro (UERJ)
}

\begin{abstract}
RESUMO
$\mathrm{Na}$ esteira dos debates sobre preconceitos raciais, três (auto)narrativas são apresentadas aqui como uma possibilidade de leitura no campo literário. Para esse exercício, foram utilizadas as obras Ruth de Souza: estrela negra (JESUS, 2007), Zezé Motta: muito prazer (MURAT, 2005) e Na minha pele (RAMOS, 2017), que contém os relatos das duas atrizes que dão nome aos livros e do ator Lázaro Ramos. Há nessas histórias uma marca em comum que, como veremos, perpassa a linha entre a ficção - campo de trabalho dos sujeitos aqui apresentados -, e a realidade: a cor da pele preta, elemento considerado durante a configuração das personagens. A possibilidade dessa leitura nos estudos literários é aqui ancorada nas ideias de Arfuch (2010), Benjamin (1994), Bourdieu (2006), Evaristo (2017), Lejeune (2014) e Lima (2013, 2014). A distância temporal entre o início das carreiras das atrizes e do ator indica alguma tentativa de mudança nas representações que lhe são conferidas, entretanto, não sem menos esforço, tanto para atuar, quanto para continuar o trabalho, tendo em vista que a recepção do público a determinados papéis continua a ser um espaço de negociação. Se por um lado os relatos sobre as experiências vividas cumprem o papel de os individualizar, diferenciando-os por suas trajetórias, por outro, a adjetivação racial a elas e a eles sempre e constantemente atribuída, entrecruza suas histórias, indicando um movimento igualmente constante de negociação de trânsitos e permanências em espaços de ficção, muitas vezes questionado em sua semelhança com a realidade, no caso, pelo que é atribuído por leituras de outrem sobre a cor da pele preta.
\end{abstract}

PALAVRAS-CHAVE: Autonarrativas. Cor da pele. Literatura. Racismo.

\section{ABSTRACT}

In the wake of the debates on racial prejudice, three (self) narratives are presented here as reading possibility in the literary field. For this exercise, the following works were considered: Ruth de Souza: estrela negra (JESUS, 2007), Zezé Motta: muito prazer (MURAT, 2005) and Na minha pele (RAMOS, 2017), which contain the reports of the two actresses who lend their names to the two first books and the actor Lázaro Ramos, respectively. There is in these stories a common feature that, as we shall see, permeates the line between fiction - work field of the subjects presented here -, and reality: the black skin color, element considered during the construction of the characters. The possibility of this reading in literary studies is anchored here in the ideas of Arfuch (2010), Benjamin (1994), Bourdieu (2006), Evaristo (2017), Lejeune (2014) and Lima (2013, 2014). The temporal distance between the beginning of the careers of the actresses and the actor indicates some attempt of change in the roles that are given to them, however, not without less effort, both to act and to continue the work, given that the reception of the public to certain roles remains a space for negotiation. If, on the one hand, the reports on the lived experiences fulfill the role of individualizing them, differentiating them by their trajectories, on the other hand, the racial adjectival always and constantly attributed to them intersects their histories, indicating an equally constant movement of negotiation of transits and stays in fictional spaces, often questioned in their

1 Doutoranda do Programa de Pós-Graduação em Letras da Universidade do Estado do Rio de Janeiro. samanta.samira@yahoo.com.br. 
resemblance to reality, in the case, to what it is attributed by others' readings about the black skin color.

KEYWORDS: Self narratives. Skin color. Literature. Racism

\section{INTRODUÇÃO}

Eu poderia lhes contar as minhas aventuras... a partir de hoje de manhã

[...] mas não adianta voltar atrás para ontem, porque eu era então uma pessoa diferente.

(Alice para a Tartaruga Falsa, personagens de Lewis Carroll)

A leitura aqui apresentada resulta de uma análise dos relatos (auto)biográficos sobre preconceitos raciais experienciados por três figuras ligadas à dramaturgia brasileira: as atrizes Ruth de Souza (1921) e Zezé Motta (1944) e o ator Lázaro Ramos (1978). Suas narrativas estão reunidas nos livros Ruth de Souza: estrela negra (JESUS, 2007), Zezé Motta: muito prazer (MURAT, 2005) e Na minha pele (RAMOS, 2017), respectivamente, a fim de pensar esses espaços biográficos em sua possibilidade de leitura no campo literário. ${ }^{2}$

Para isso, os seguintes aspectos sobre as citadas trajetórias foram considerados: (i) a cor da pele preta como uma marca ${ }^{3}$ indissociável de cada história, muitas vezes campo de enfrentamentos e negociações de espaços profissionais já inicialmente delimitados por essa (não) razão; e (ii) o espaço temporal marcado pelo início das carreiras das atrizes e do ator em questão, que compreende, por exemplo, quase cinquenta anos entre os primeiros palcos de Ruth e os de Lázaro. Esse fato pode ser um indicador de possíveis, mesmo que ínfimas e pontuais, mudanças em cenários - não somente ficcionais - de manifestações de racismo ditas, não ditas e sentidas. Há quem as consegue perceber, há quem as questione, e há quem as pode contar e publicar, como nos casos que serão aqui apresentados, exceções que sabemos que confirmam o que nos é recorrente na realidade, pelas tentativas da lógica que opera o racismo, de delimitar territórios e trajetórias.

O entrecruzamento dessas trajetórias em espaços de exceção - confirmações disso são as vivências de ter sido a primeira atriz negra a interpretar determinada personagem, na década de 1940; ou o primeiro galã negro, somente no ano de 2011 - revelam que a adjetivação racial que acompanha seus ofícios, algo que compreende do desenho e escolha de personagens e roteiros até a aceitação desses pelo público e entrevistas com os atores, são determinantes em suas trajetórias e, assim, em suas narrativas sobre elas. O que essa exceção talvez permita, seja uma alteração muito gradativa nos imaginários historicamente construídos e perpetuados pelas composições de personagens ficcionais, escritas ou encenadas, mas que chegam ao leitor e ao público delineando personagens, enredos e até mesmo realidades, a partir de seus corpos.

Essas trajetórias nos são apresentadas de formas diferentes pelas obras aqui estudadas, sendo importante elucidarmos aqui outros sujeitos que as compõem. As narrativas de Ruth de Souza e de Zezé Motta são apresentadas como biografias e advêm de entrevistas feitas por Maria Angela de Jesus (2007) e por Rodrigo Murat (2005), cujo objetivo foi o resgate das memórias das atrizes - no caso de Zezé, também cantora - como parte da historiografia cênica brasileira. Os relatos integram uma série de biografias, distribuída em escolas da rede pública de ensino do Estado de São Paulo ${ }^{4}$. Talvez por esse motivo, a forma linear e objetiva como as histórias são narradas,

\footnotetext{
2 O presente estudo se origina das leituras feitas para o trabalho de conclusão da Especialização em Literatura Brasileira, na Universidade do Estado do Rio de Janeiro (UERJ), orientado pelo professor Ítalo Moriconi.

${ }^{3}$ Conceito e discussão desenvolvidos pelo professor Oracy Nogueira (1917 - 1996) em seu estudo intitulado Preconceito racial de marca e preconceito racial de origem: sugestão de um quadro de referência para a interpretação do material sobre relações raciais no Brasil”. Disponível em: https://www.revistas.usp.br/ts/article/view/12545/14322.

${ }_{4}^{4}$ Publicadas na Coleção Aplauso, projeto promovido pela Imprensa Oficial do Estado de São Paulo.
} 
tendam a assumir um discurso mais pedagógico. Essa evidência pode ser observada, por exemplo, nos textos de apresentação das coleções, a partir de afirmações como: "são inúmeros os artistas a apontarem o importante papel que tiveram os livros e a leitura em suas vidas, deixando transparecer a firmeza do pensamento crítico, ou denunciando preconceitos seculares que atrasaram e continuam atrasando nosso País"; ou quando Ruth de Souza é apresentada como alguém cuja formação cultural, definidora de sua trajetória, se deu às custas de muito sacrifício, negando, dessa forma, elementos como o acaso, e evidenciando, em seu detrimento, a autodeterminação (JESUS, 2007, p. 16).

Pela citada motivação para as obras e suas destinações, as narrativas distanciam-se do desenvolvimento em espaços de subjetividade. Assim, como recurso para contar histórias de forma objetiva, os biógrafos Maria Angela de Jesus (2007) e Rodrigo Murat (2005) mantiveram as vozes das atrizes em primeira pessoa, como se elas estivessem dialogando diretamente com o leitor. Por esse motivo, as perguntas, inferências e observações feitas pelos autores não aparecem de forma direta no texto, por mais que saibamos que seus trabalhos envolvam pesquisa, observação, condução, seleção de fatos e escolha da sequência e forma de escrita dos relatos, ficando então seu discurso direto, a voz do biógrafo, presente apenas nas introduções das duas biografias.

Assim, podemos dizer que temos em cada uma das obras, e em sua totalidade, a coexistência de dois sujeitos: (i) o entrevistador, que assume a função de biógrafo, considerando seu trabalho de pesquisa, condução e organização dos relatos; e (ii) o entrevistado, cuja enunciação é marcada pelo já exposto uso da primeira pessoa das duas atrizes, delineando, dessa forma, um eu que assume a função do contar sobre si, mesmo, como sabemos, esse contar tendo se dado através da figura do biógrafo. Essas configurações se diferem do que acontece em Na minha pele (RAMOS, 2017), onde quem assume o papel da enunciação é Lázaro Ramos, figurando então como autor-narradorpersonagem, caracterizando, assim, sua escrita como autobiográfica.

Diante das citadas especificidades que envolvem as escritas de Jesus (2007), de Murat (2005) e de Ramos (2017), nas quais temos obras formadas (i) por autora, autor e atrizes, estas figurando também como autoras de seus relatos, mas não da escrita que compõe as duas biografias; e (ii) autor de uma história que é sua, figurando, assim, como personagem e compondo uma escrita autobiográfica. Considerando essas diferenças, tomamos emprestada a seguinte expressão utilizada por Arfuch (2010): narrativas vivenciais, que as indicam como "núcleo essencial de tematização" (p. 16), acrescidas, pelos motivos aqui mencionados, do prefixo auto-, entre parênteses, como forma de, no decorrer da escrita, manter em evidência a composição de cada obra, ambas, com foco nas experiências vividas pelos sujeitos pesquisados, entrevistados e que se enunciam. No caso aqui estudado, narrativas sobre trajetórias profissionais na dramaturgia e teledramaturgia brasileira, entrecruzadas pela experiência do racismo.

Este texto está dividido em três partes e mais algumas considerações finais. A primeira parte se subdivide por conter a compilação das histórias de Ruth de Souza, de Zezé Motta e de Lázaro Ramos acerca de suas percepções sobre os momentos nos quais as suas cores de pele foram pauta para questionamentos, recorte esse que tece a presente escrita. Por esse motivo, essa primeira parte constitui-se predominantemente expositiva e sem a sequência temporal disposta em cada livro, pela liberdade desse exercício de lá e cá requerido pela escrita que aqui se apresenta, que é também uma outra forma de narrar; a segunda parte é composta pelas leituras teóricas acerca das (auto)narrativas vivenciais e ocupa-se do falar sobre a pele que habitamos sob a perspectiva de uma possibilidade de leitura literária; na terceira e última parte, as narrativas são entrecruzadas como forma de pensarmos suas construções como um espaço - defesa do estudo que aqui se apresenta - nos quais figuram os sujeitos que as enunciam.

As vozes aqui acionadas para nossa leitura, são as de Arfuch (2010), Benjamin (1994), Bourdieu (2006), Lejeune (2014), Lima (2014) e, destaco uma que perpassa todo esse texto: a da escritora Conceição Evaristo, por suas precisas - aqui nos dois sentidos da palavra - definições e observações sobre o vivido e sobre o narrado. 
Antes de seguirmos, por uma questão de fluidez do presente texto, peço licença para utilizar em muitos momentos apenas o primeiro nome das atrizes e do ator que enunciam suas trajetórias. Assim, Ruth, Zezé e Lázaro.

\section{A pele que habitamos: vozes que se acrescentam}

"Se ninguém sabe que eu sou a Conceição Evaristo [...]". Durante o evento de lançamento da coletânea de contos e crônicas Olhos de ąeviche: dez escritoras negras que estão renovando a literatura brasileira (Editora Malê, 2017) ${ }^{5}$ a premiada escritora Conceição Evaristo contou sobre uma situação na qual the perguntaram se ela sabia assinar. Ao responder que sim, a autora disse que gostava muito de escrever e de ler e que ao se despedir entregou seu cartão. Ao público que a ouvia, ela disse: "claro, horrível, né? mas eu fiz isso e estava lá, Doutora em Literatura e blá blá" e finalizou: "o racismo é imperdoável mesmo".

Não há como rotularmos situações que envolvem o racismo como tênues, mas há que se reconhecer que suas manifestações cotidianas se dão desde ações como as acima narradas até o acreditado livre trânsito pelos corpos negros de outrem, como se fossem um território para mando e desmando, como podemos ver nos seguintes depoimentos de Ruth (JESUS, 2007), Zezé (MURAT, 2005) e Lázaro (RAMOS, 2017), nessa mesma ordem:

Como é que você vai ser artista, você é negra! Não tinha negro nem no próprio cinema americano, ou melhor, o negro era muito maltratado, mal-representado. A presença negra era sempre de criadas e criados ou caricaturas [...]. Muitas vezes as pessoas não acreditavam que uma menina negra tivesse sonhos - e quando digo isso é a mais pura verdade [...]. Ficava de olho grande, vendo as outras meninas estudando piano, pois queria muito aprender a tocar. $\mathrm{E}$ as pessoas riam quando eu dizia isso e faziam comentários maldosos: Imagina! Olha, o que ela quer! Ela quer ser artista! Não tem artista negra, como é que ela quer ser artista?! (JESUS, 2007, p. 29, 30).

Quando montamos Os Viajantes, auto de Natal da Maria Clara Machado, quase fomos apedrejados pelo público. Fizemos a apresentação entre os pilotis, no vão central dos edifícios, e quando os moradores deram com uma Virgem Maria negra, feita por mim, e um José crioulo, interpretado pelo meu saudoso Zaqueu, já falecido, começaram a atirar ovos e a vaiar. Tivemos que interromper e continuar a sessão no pátio do colégio. Para você ver que o preconceito está enraizado mesmo entre negros e pobres.

(MURAT, 2005, p. 26).

[...] prefiro falar de Insensato Coração, de 2011, uma novela de Gilberto Braga em que, segundo a imprensa, eu fazia o primeiro galã negro da televisão brasileira. [...]. Eu estava inebriado com a nova história que estava sendo construída, uma história de livre criação e de otimismo para os até então excluídos [...]. Não sabia que seria tão forte a reação. Além de ser chamado de canastrão, fui atacado ferozmente nas redes sociais. Muita gente me chamou de feio, de macaco, de inadequado para o papel. Claro que é mais complexo do que isso, porque estava colocado ali o desejo sexual das mulheres. Eu, felizmente, sei por experiência própria que o desejo na vida real não se enquadra no padrão do galã de traços quase femininos, olhar chorão, cabelo liso penteado para o lado. O fato é que essa cara com rosto negroide, boca e olhos grandes, nariz largo sofreu uma rejeição (RAMOS, 2017, p. $104-106)^{7}$.

\footnotetext{
${ }^{5}$ Auditório Machado de Assis, Biblioteca Nacional, março de 2017.

${ }^{6}$ Notas sobre a palestra assistida.

7 Uma breve pesquisa através do filtro de imagens do Google pelo nome da novela, "Insensato Coração", revela um curioso, mas não tão surpreendente contraste: a imagem do personagem de Lázaro Ramos, mesmo diante de seu papel de protagonista, aparece em uma proporção, somente nas sessenta primeiras imagens, de quatro para sessenta, sendo quatro imagens suas, e as demais de outras personagens da novela. Disponível em: https://www.google.com/search? $\mathrm{q}=$ Insensato + Cora $\% \mathrm{C3} \% \mathrm{~A} 7 \% \mathrm{C} 3 \% \mathrm{~A} 3 \mathrm{o} \&$ source $=\operatorname{lnms} \& \mathrm{tbm}=$ isch\&sa $=$ X\&ved $=0$ ahUKEwjpgJzF3 $-3 \mathrm{hAhUTIbkG}$ HSwjAVIQ_AUIDygC\&biw=1366\&bih=625. Acesso em 26 abr. 2019.
} 
A geração de sentidos feita pela cotidiana leitura sobre a cor da pele é vivida, praticada e delimita espaços e lugares aceitáveis - ou não - de existências - ou não - em determinados lugares. Esses sentidos são muitas vezes gerados após o, acredita-se, simples ato de chegar, caminho primeiro para a entrada em qualquer lugar, em qualquer atividade. A leitura feita e recebida ao chegar, em todos os casos narrados tocam na (cor da) pele de cada um que chega e torna a chegar, mesmo em espaços temporais tão distintos. Mesmo na representação artística, um dos principais cenários aqui apresentados e por ser campo de trabalho de Ruth, Zezé e Lázaro, a verossimilhança das obras foi e continua passível questionamentos sobre as peles de quem atua, por vezes utilizada como justificativa para questionar a qualidade das produções artísticas nas quais cada atriz e ator estavam envolvidos.

Esse movimento de estar nos espaços, sendo questionada, questionado e questionando aponta para as negociações feitas diante de todas as "demandas do preconceito." (RAMOS, 2017, p. 102). É como se suas/nossas humanidades tivessem que ser negociadas em cada passo e cada um desses passos nos conduziu a 2017, ano de lançamento da autobiografia de Lázaro Ramos, na qual, como veremos nos próximos tópicos, nos deparamos com as mesmas tensões vividas pela, ainda menina, Ruth de Souza.

\subsection{Toda negra se chama Sebastiana! Toda negra não, eu me chamo Ruth!}

A atriz é retratada por sua biógrafa, Maria Angela de Jesus (2007), a partir do universo da Ruth de Souza ainda menina, de origem simples, negra - adjetivo, como veremos no próximo parágrafo, encontrado do título ao fim do livro - e que sonhava em ser artista. Essa cena culmina na premiada atriz com mais cinquenta anos de carreira, altiva, vaidosa, elegante, de voz tranquila, porém firme, e boa contadora de histórias, segundo a apresentação feita pela biógrafa. O cenário é uma casa iluminada em tarde de primavera e é composto por uma estante de madeira na qual estão os prêmios, filmes e livros da atriz; uma imagem de Nossa Senhora da Conceição em cima de sua televisão e uma parede com pôsteres dos filmes por ela atuados e fotografias de sua carreira, como a de Desdêmona, de Otelo 8 , “a primeira Desdêmona negra!” (JESUS, 2007, p. 17).

Ainda na introdução, a biógrafa anuncia que a atriz diz evitar fazer discursos sobre preconceito racial, mas, pelos motivos apresentados no texto de introdução deste trabalho e que conduzem a narrativa para uma escrita que forja a primeira pessoa de Ruth, percebemos que são justamente esses discursos que perpassam sua narrativa, a iniciar, como vimos, pela opção do subtítulo: "estrela negra". Por vezes a linearidade dos fatos chega a ser suspendida para que ela os relacione com os preconceitos vividos. Ela não só denuncia questões nas quais foi tão somente a cor de sua pele o fator de conflito posto pela direção das produções nas quais atuou, como reflete sobre os papéis desenhados para atrizes e atores negros, muitas vezes com o objetivo de "enfeitar" a trama. Não deixemos de considerar, diante do cenário de escrita que envolve biógrafo e biografada, que o o que narrar é uma escolha consciente e proposital. É, assim, pautando experiências entrecruzadas por preconceitos, que a história da atriz segue.

A projeção de Ruth nas telas de cinema não soma duas horas, fato por ela justificado por não ter sido atriz principal na sétima arte. Em sua biografia estão, entre os anos de 1948 a 2004, elencados trinta e um filmes. Antes mesmo que pensemos nos porquês, ou junto a eles, é a própria Ruth quem nos explica:

Lembro-me de quando estava trabalhando em Sinhá Moça, no papel de uma escrava. Era comum ver os escravos retratados de um jeito imbecil, bobo [...] é uma pena que nossas figuras históricas sejam tão ridicularizadas. Repare como os roteiros são construídos de forma a ridicularizar nosso passado [...]. Não acho correta essa vulgarização que se faz de nossa história. O brasileiro gosta de fazer chacota com coisa séria. Nas novelas o menino

\footnotetext{
${ }^{8}$ Montagem do primeiro ato de Otelo, obra de William Shakespeare, pelo Teatro Experimental Negro, dirigido por Abdias do Nascimento.
} 
negro é sempre trombadinha. O homem negro é bandido, violento, ou então é segurança. O curioso é que, quando questiono sobre essa situação do negro, me respondem: Nós estamos mostrando a realidade. Qual realidade? Já fizeram mulher que explodia, homem que voou, homem que subiu à Lua. Novela é ficção. Lembra do homem que tinha formiga no nariz? Mas quando se trata do ator negro, começam com essas mesmas desculpas. (JESUS, 2007, p. 23).

Nessa realidade sobre a construção ficcional figura a cor da pele, passível de desenhos que podem imbecilizar, zombar e assim, perpetuar estereótipos que, nos casos listados por Ruth, recebem a proteção do falacioso discurso do necessário diálogo entre ficção e realidade, pondo em questão a verossimilhança de apenas e seletivamente, determinadas obras. Sua crítica compreende, pois, a quantidade de personagens feitas para "enfeitar" a trama, sem história, "sem pai nem mãe, sem passado". Percebido isso e como recurso a esse constante esforço de negação de silêncios, Ruth tentava transformar essas personagens em "alguém" dentro da trama, inventando "um lugar de onde aquela pessoa tinha vindo, [...] uma família, mãe e pai", afirmando que é papel do ator “fazer o personagem pensar!” (JESUS, 2007, p. 86,98).

Há um limite delimitado nesse discurso contido no "mostrar a realidade" que podemos dizer que é um lugar ocupado por Ruth - e, adianto, por Zezé e por Lázaro - quando sua cor de pele é objeto de justificativa e desenho de personagens: esse lugar entre ficção e realidade se (con)funde ao revelar situações como a em que a atriz teve seu nome posto no final dos créditos de uma novela, depois de todas as outras atrizes e de todos os outros atores, mesmo sendo a atriz principal. A atriz complementa: "a minha luta eterna é para ter meu nome creditado em meus trabalhos. Hoje em dia, peço para ter meu nome creditado como participação especial. Já é difícil segurar o público, marcar seu nome, imagina se não temos crédito.” (JESUS, 2007, p. 98. Grifos meus). À essa questão, alia-se o habitual confundir Ruth com outras atrizes negras, aspecto, como veremos, também elucidado por Lázaro:

Nós somos negros. Um homem negro, uma criança negra. Dizer aquela mulher é negra, não é ofensa, mas parece que há um certo medo da palavra. Em vez de falar o negro, dizem moreno, escurinho. Não têm coragem de falar negro. E sempre nos confundem. Parece que negro é tudo igual. Por exemplo, às vezes me confundem com outras atrizes negras. Fico furiosa! Não gosto de ser comparada, nunca gostei (JESUS, 2007, p. 88, 89).

"Nome" foi território a ser conquistado e objeto de questionamento, dessa vez sobre uma personagem que seria interpretada por Ruth e que recebeu o mesmo nome de outra, por ela interpretada dois anos antes:

por que o nome da personagem é Bastiana? Não tem outro nome? Já era Bastiana no Terra é Sempre Terra ${ }^{9}$. E ele contestou: Toda negra se chama Sebastiana! Retruquei, com calma mas firme: Toda negra não, eu me chamo Ruth! Então bota outro nome! ele me falou. E eu escolhi Manuela (JESUS, 2007, p. 32, 33).

Para a atriz, movimentos como esse podem mesmo ser inconscientes, sem maldade e objetivos de ferir, mas ainda assim sugestionados por preconceitos absorvidos "pela vivência, pelo hábito, pela vida", fazendo com que sejam assumidos "certos estereótipos como se fossem verdadeiros" (JESUS, 2007, p. 32, 33). Esses (não)limites entre ficção e realidade aparecem também nas narrativas que seguem, de Zezé Motta e de Lázaro Ramos.

\footnotetext{
9 1951, filme brasileiro dirigido por Tom Payne e baseado na peça Paiol Velho, de Abílio Pereira de Almeida, também autor do roteiro.
} 


\subsection{Sobre cenas, sambas e enredos: Zezé Motta}

É também o biógrafo quem apresenta Zezé Motta: muito prazer ${ }^{10}$. A atriz é desenhada por Murat (2005) como uma pessoa risonha, filha de Oxum com Iansã e que entre as tantas viagens à época da entrevista, parou em frente ao gravador para contar sua história. Também como alguém que nega o "Era uma vez...", indicando uma história distante dos contos de fadas (MURAT, 2005, p. 13). Pode-se dizer que as páginas seguintes à apresentação formam, à medida que se encadeiam, um palco para Zezé, a partir do momento em que a voz da atriz e cantora entra em cena, pela já enunciada opção de escrita da biografia através do uso da primeira pessoa do discurso.

Tal como nas narrativas de Ruth e, adianto, nas de Lázaro, a história contada por Zezé é iniciada pelo desenho de sua infância. Seu eu-menina" gostava de se "exibir, declamava poemas e escrevia poesia" e fazia parte de uma família de origem humilde, na qual sua mãe estava à máquina de costura ao mesmo tempo em que seu pai tocava violão, com o rádio sempre ligado, início do fascínio da futura atriz e cantora pela música ${ }^{12}$. A responsabilidade pelo início da formação de sua consciência política, dita de esquerda, sobre as injustiças sociais é atribuída à sua educação escolar ${ }^{13}$. A partir daí a narrativa segue pela construção da carreira de Zezé sob o cenário cerceador dos "anos de chumbo" pela Ditadura Militar no Brasil (MURAT, 2005, p. 22, 23).

"Volta e meia eu esbarrava nessa historinha de preconceito" é uma afirmação presente logo no início da narrativa de Zezé e que permeia os relatos sobre sua carreira, com as recorrentes perguntas sobre "ser atriz, mulher e negra", questionamento igualmente presente nos relatos feitos por Lázaro Ramos. Ainda na escola, mas em já processo de subir aos palcos, a atriz contou sobre o que chamou de "experiência curiosa", quando ao interpretar uma Virgem Maria negra, adjetivação expressa em seu relato, foi alvo de vaias e ovos, mesmo de negros e pobres como ela, resultado, segundo a atriz, de preconceitos enraizados e, como vimos nos relatos de Ruth, embasando a questão de determinado corpo não caber em dados personagens. Todas as narrativas que seguem a partir daqui envolvem palco, câmera, encenação e cor da pele como questão, como uma marca caracterizadora e caracterizada (MURAT, 2005, p. 25).

Quando aos vinte e dois anos conseguiu uma bolsa de estudos para uma escola de teatro, uma vizinha maldou: "ué, não sabia que para fazer papel de empregada precisava de curso". Sua estreia e tantas outras atuações se deram justamente nesse papel. De acordo com o relato, um dos autores que convidou a atriz chegou a enfatizar que o papel de empregada para o qual a convidara não seria para "servir cafezinho e abrir porta, não", pois ela se divertiria com a personagem, algo que ela afirma ter acontecido (MURAT, 2005, p. 39).

Empregada é um papel que lhe foi tanto desenhado e encenado que chegou a virar ala $\mathrm{da}$ escola de samba cujo enredo homenageava a atriz ${ }^{14}$ (MURAT, 2005, p. 70). Mesmo sua atuação no premiado Xica da Silva ${ }^{15}$ não mudou esse cenário. Quando o foi lançado, Zezé Motta estava em cartaz no teatro em uma comédia na qual atuava como empregada. Sua personagem, de "papel minúsculo [...] tirava o pó dos móveis e provocava o patrão, naquela tradição de mucama que dá mole pro senhor" e não tinha nenhuma fala. Com o lançamento do filme, o seu nome foi aumentado no cartaz da peça para que as pessoas fossem ver a "atriz de Xica da Silva”. Igualmente,

\footnotetext{
10 Título inspirado na canção "Muito Prazer Zezé", comporta por Rita Lee e Roberto de Carvalho em 1978, mesmo à época conhecendo a atriz somente através das entrevistas por ela concedidas.

${ }^{11}$ Expressão emprestada do livro Becos da memória, da autora Conceição Evaristo.

12 Os "reis da voz" que tocavam em seu rádio eram Ângela Maria, Nora Ney, Cauby Peixoto, Marlene, Emilinha, Jorge Goulart, Ellen de Lima (MURAT, 2005, p. 23).

${ }^{13}$ Foi aluna do Instituto fundado por dom Hélder Câmara, à época Colégio Santos Anjos, na Cruzada São Sebastião, que abrigava os ex-moradores da comunidade que existia na extinta Praia do Pinto, atual região da Lagoa Rodrigo de Freitas - RJ.

14 Grêmio Recreativo Escola de Samba Arrastão de Cascadura, 1989, samba enredo Zezé Um Canto de Amor e Raça. Disponível em: http:/ / www.arrastaodecascadura.no.comunidades.net/sambas-enredo-antigos. Acesso em 19 mai. 2018. 15 1976, filme dirigido por Cacá Diegues.
} 
essa propaganda também impulsionou sua carreira como cantora, inclusive nos Estados Unidos (MURAT, 2005, p. 55). À ocasião do lançamento do filme, Zezé recusou um convite para atuar como uma personagem que servia doces. O seu bradado "empregadas, nunca mais!" lhe rendeu um longo período sem convites para a teledramaturgia, que só cessou quando a mesma emissora a convidou para encenar uma empregada que "fazia parte da trama", ao manter um caso com dois irmãos dos quais era faxineira. Mesmo que vejamos outras questões aqui, como a historicamente construída tentativa de sexualização das mulheres negras, segundo a biografia, o problema da atriz com os demais papeis de empregada era com o também característico "entrar muda e sair calada" (MURAT, 2005, p. 57).

Corpo em pauta, "cabelo ruim, nariz chato, bunda grande", esses desenhos conduziram a atriz a um por ela declarado "estado de alienação", pois queria "ser branca, ter nariz afilado, cabelo liso" para que suas atuações fossem aceitas. Seu confronto com essa questão só se deu durante uma turnê de teatro nos Estados Unidos, no auge do black is beautiful ${ }^{16}$, quando os militantes desse movimento se estarreceram com a atriz se apresentando com uma peruca lisa (MURAT, 2005, p. 27, 46). Se falamos de liberdades, ela não era possibilitada por nenhum dos holofotes a ela direcionados, nem os que tinham como público os que não se intitulavam racistas, por não se verem como tal, nem os que tinham como público os que se intitulavam não-racistas.

De acordo com a biografia de Zezé, um diretor sempre dizia quando ela estava próxima ao ator que era seu par em uma novela": lá vem o casal "black and white". O "tabu [...] do relacionamento inter-racial" também foi vivido anos depois, quando o casal do qual fazia parte era ridicularizado pelo público, por não os conceber como um casal. Tais cenas, como outras dessa mesma nota só, colocaram a verossimilhança do roteiro em dúvidas e ultrapassaram os limites da ficção, quando o público especulou que o ator só poderia estar precisando de dinheiro para se sujeitar àquela acreditada forma de "humilhação" (MURAT, 2005, p. 40, 71).

Nessa mesma questão da seletiva necessidade de semelhança com a realidade, aos vinte minutos do início de um espetáculo, a aparição de Zezé como uma condessa cuja serviçal era loura atarantou a plateia pela "farsa" daquela cena ${ }^{18}$. De volta ao papel de empregada, a garantia de maior participação não foi consolidada, pois a censura militar julgou sua personagem como alguém que "se metia demais na vida dos patrões", fazendo com que o diretor a redesenhasse para que servisse cafezinho e abrisse porta (MURAT, 2005, p. 100, 40).

Como cantora, Zezé também não escapou a tais questões, pois não lhe foi possível transitar por gêneros musicais para além do samba. Sua breve tentativa de fuga do rótulo de sambista, fundamentada pelo fato de não querer contribuir para a alimentação desse estereótipo sobre pessoas negras foi por ela chamada de uma "fase de militância mais radical" e foi interrompida ao ter sido convencida pela gravadora sob o argumento das vendas abaixo do que esperavam: "aí já era uma questão de mercado, eu não podia botar a militante à frente da artista e topei fazer um disco de sambas" (MURAT, 2005, p. 63-65).

Aí eu lembrava da Lélia Gonzales ${ }^{19}$, que eu conheci num curso de cultura negra no Parque Lage, dizendo que não se pode sofrer com esses comentários e que é preciso manter a cabeça erguida. Porque ficar de vítima reclamando é muito fácil. Fácil, chato e contraproducente [...]. Na época da Xica, eu dava média de três entrevistas por dia, e as pessoas sempre perguntavam sobre ser atriz, mulher e negra. Senti que eu precisava aprimorar o meu discurso. Nisso, a Lélia me ajudou. Lembro que na aula inaugural ela

\footnotetext{
${ }^{16}$ Movimento cultural antirracista iniciado nos anos de 1960 nos EUA.

${ }_{17}$ Corpo a Corpo, escrita por Gilberto Braga, com colaboração de Leonor Bassères, produzida e exibida pela Rede Globo entre 1984 e 1985.

18 Fígaro on um dia muito louco, 1972. Montagem da comédia de Beaumarchais (1732-1799) pelo diretor Gianni Ratto (1916 - 2005).

191935 - 1944, professora de história e filosofia, antropóloga, negra e uma das fundadoras do Movimento Negro Unificado (MNU).
} 
disse: Não temos mais tempo para lamúrias. Temos que arregaçar as mangas e virar esse jogo (MURAT, 2005, p. 71-73).

Esse movimento de entender a lógica de produção de tais cenários se dão ao passo em que Zezé revela seus processos de tomada de consciência sobre as possibilidades de trânsito de seu corpo, assuntos "a respeito de cidadania" aos quais se dedicou em experiências como a dos três anos em que foi Conselheira dos Direitos Humanos, no governo de Fernando Henrique Cardoso (MURAT, 2005, p. 79). Os espaços questionados por Zezé nos indicam, sobretudo, os limites desenhados para a sua figuração, predominantemente limitada por um tipo de personagem, e que a marca temporal de mais de vinte anos entre o início de sua carreira e a de Ruth e a de Lázaro, autor-narrador-protagonista da terceira e última narrativa aqui estudada, aponta justamente para seus trânsitos como uma possível palavra-chave de aproximação dessas narrativas para a leitura aqui proposta.

\subsection{0 único galã negro, segundo a imprensa, ou o Lázaro Ramos}

“- Como é fazer um médico, arquiteto, surfista, Roque Santeiro, boêmio da Lapa, padre, gay, ou seja, lá quem for... negro?”. Segundo Lázaro Ramos, no prólogo de seu livro Na minha pele (2017), essa adjetivação racial faz parte das perguntas mais ouvidas por atrizes e atores negros como vimos, apontada também por Zezé Motta - e para a qual ele diz sentir vontade de dizer não saber, justamente pelo fato de nunca ter feito nenhum personagem de pele verde (p. 10).

É a partir da ótica de quem é "o único negro" em muitos espaços, de quem viveu os "desafios de ascender socialmente", que as perguntas retóricas, citações de diálogos e interjeições presentes no prólogo da autobiografia desenham o processo de negação inicial do ator à proposta feita pela editora para que ele escrevesse um livro relatando sua experiência como ator negro e movem-se justamente para sua autobiografia, que é o terceiro objeto de investigação deste trabalho: o livro Na minha pele (RAMOS, 2017, p. 12). Lázaro diz reconhecer o privilégio de seu "poder dizer" e justifica a partir desse ponto a sua escrita, que pretende tratar das dores do racismo sofrido e observado, pelas possíveis funções sociais dessa história contada.

Sua condição de exceção não o blindou, porém, da rejeição sofrida quando atuou no papel de galã, nem da decorrente animalização ao ter sido chamado de macaco, nem mesmo da naturalização de uma mulher que, no ano de 2016, que está logo ali, ao confundi-lo com um ladrão não entendeu o porquê de ele ter se ofendido. Assim como Ruth, ele também foi confundido por uma atuação que não foi sua, na qual a personagem empunhava uma arma de fogo ${ }^{20}$. $\mathrm{O}$ ator salienta, no decorrer de toda a sua escrita, a necessidade de reflexão sobre quais são os corpos mais comuns em tantas narrativas, ficcionais ou não. Mais que isso, se diz resistente ao convite de encenar personagens portando armas de fogo (RAMOS, 2017, p. 139, 99).

Diferente do que lemos nas narrativas de Ruth de Souza (JESUS, 2007) e de Zezé Motta (MURAT, 2005), verbos como "decidir" e "recusar" são muito mais presentes nos relatos de Lázaro Ramos e compõem histórias como a da sua decisão de ao ter que empunhar armas em cena o fazer de forma a sugerir o desconforto de suas personagens com tal situação, indicando, de alguma forma, que sua mão não era o lugar daquela arma; outra história relatada nessa mesma linha é a de sua recusa a dois convites para encenar a peça Otelo, pois o ator aceitaria somente se pudesse viver o Iago ${ }^{21}$, algo até então não permitido pelos diretores das montagens (RAMOS, 2017, p. 99 $102,107,110)$.

A história é iniciada por Lázaro a partir de uma breve carta destinada à sua já falecida mãe, para só então dialogar com a (o) leitora (or). O partir da infância, lugar da autopercepção de sua etnia, é desenhado pelo lado de fora de uma corda de camarote de carnaval, marcação de um não

${ }^{20}$ Refere-se a Zé Pequeno, personagem interpretado por Leandro Firmino da Hora em Cidade de Deus, 2002. Direção de Fernando Meirelles e Kátia Lund.

21 Obra de William Shakespeare, referenciada também no tópico sobre a atriz Ruth de Souza. 
lugar em sua terra, e ganha som e ritmo com o repicar dos tambores que bradam "eu sou negão! [...] meu coração é a liberdade". Nesse exercício de ver-se, o ator reconhece esse bradar como algo não cotidiano em sua infância, pois em casa, embora de autoestima declarada, diziam "a gente, que é assim [...] tem que andar mais arrumadinho" (RAMOS, 2017, p. 26,27, 35. Grifos do autor).

A narrativa percorre sua vida na escola; o gosto pela literatura; a entrada para o Bando de Teatro Olodum, para a televisão e para o cinema; bem como pontos de sua vida para além das telas, revelando ao leitor questionamentos sobre suas próprias relações de afeto e de responsabilidades como filho, como pai e como companheiro. O autor declara ainda seu cansaço diante de situações nas quais ele lê o racismo implícito que perpassa seu cotidiano e, assim, sua necessidade de se reservar para refletir sobre a efetividade de suas respostas. Tais espaços são ditos por ele ao leitor como confortáveis de serem narrados, tendo em vista esse pacto de declarada intimidade permitida entre quem diretamente narra e quem lê (RAMOS, 2017, p. 117, 121).

Conversando com Taís, ela uma vez me perguntou: "Como é que você consegue ficar pensando nisso tudo? Será que esse não é um fantasma que seria melhor ignorar?”. Certamente, mas como sou prisioneiro de mim, tenho prazer em observar essas sutilezas do processo identitário cultural e organizacional do meu país. Qualquer pessoa é capaz de viver com esse fantasma? Até quando vou conseguir seguir dessa maneira? Me responda, você do futuro. O que aconteceu depois que esta história foi escrita? (RAMOS, 2017, p. 107).

Seu trânsito por vários cenários é, por vezes, marcado por negociações da forma como aparecerá em determinados espaços, marcados pelas "sutilezas" vivenciadas, assim questionadas: “ai, meu Deus, lá vou eu ser tratado de novo como ator negro e não como ator" (RAMOS, 2017, p. 89). É o próprio Lázaro quem nos situa:

\begin{abstract}
Eles queriam que a mensagem no cartaz fosse algo relacionado ao consumo, e a sugestão deles era: Não vai comprar porque ele é negro? Polêmica à vista. Para quem não sabe, prezo a discrição e nunca gostei de me envolver em polêmica. [...] eles conseguiram, depois de muita negociação, me deixar menos constrangido para fazer fotos - segundo eles - sensuais. Enfim, chegamos a uma conclusão sobre a frase. "Compro e vendo" seria a manchete. Um bom símbolo de que nós, negros, temos voz como consumidores e também queríamos nos ver na mídia anunciando produtos. Fiquei feliz, fui pra casa e esperei um mês até ver a revista nas bancas. 13 de outubro de 2005. Olha lá a TPM! NÃO VAI COMPRAR PORQUE ELE É NEGRO? BONITO, 14 FILMES, ATOR DA GLOBO. NUNCA FOI CHAMADO PARA UMA GRANDE CAMPANHA PUBLICITÁRIA. POR QUE SERÁ? (Idem).
\end{abstract}

Junto a essas negociações, percebemos seu movimento de busca pela reinterpretação de seus sentidos sobre o que é dito sob o binômio ator-negro, quando, por exemplo, trava um diálogo consigo sobre a citada mudança da frase: "eles não têm esse direito!", e segue: "Ou têm? [...] A minha pele foi mais enfocada do que meu trabalho" (p. 89). Ainda nesse exercício, recorre à carta recebida do diretor da companhia de teatro do início de sua carreira ${ }^{22}$, apresentada em sua autobiografia: "Sim. É uma marca. O negro é estigmatizado aqui e não há como negar. Há então que assumir-se diferente e, com esta diferença, marcar a história deste país. [...]. Exercer seu papel de protagonista neste enredo" (RAMOS, 2017, p. 89 - 90).

$\mathrm{O}$ ator revela que estrategicamente tece elogios sobre o talento de atrizes e atores negros a diretores, num movimento de "passar o recado", por um processo de delicadeza que é consciente, dado que em determinadas situações é o único caminho possível (RAMOS, 2017, p. 92).

Quanto mais o tempo passava, mais eu sentia que eles prestavam atenção no que eu falava. Eu não estava fazendo uma panfletagem explícita. Hoje em dia, de vez em quando,

${ }^{22}$ Márcio Meirelles, que, com Chica Carelli, criou no ano de 1990 o Bando de Teatro Olodum, por ele dirigido até hoje. 
acho importante falar para incomodar. Mas naquele momento, decidi que existiam questões que não precisavam ser ditas, tinham de ser pensadas. Nessas discussões e negociações, de vez em quando a preguiça impera. É mais fácil escolher um argumento como defender que no Brasil o racismo é mais brando - e insistir nele, dizendo que tudo é mimimi ou mania de perseguição. Sem assumir a complexidade, nada muda de lugar (RAMOS, 2017, p. 57,58).

O capítulo intitulado "conexão" tem somente uma lauda e a escrita formatada linha a linha, centralizada como os versos de um poema marca a transição da forma como Lázaro passa a abordar a questão racial que perpassa sua escrita. Após anunciar sua necessidade de "fazer uma parada", pois as perguntas feitas até então pelo autor-narrador-protagonista foram para ele próprio, voltase para o leitor e pergunta: "quando, neste livro, eu sou você? Onde nos encontramos? [...] Sei que talvez eu fale sobre alguns temas com aquela espécie de impostação que lembra os abolicionistas nas séries de TV brasileiras. Por outro lado, como não ser assim?” (p. 71).

Embora a escrita seja predominantemente autobiográfica, no decorrer do livro e sobretudo a partir desse momento da narrativa, o autor anuncia outras vozes como um meio para questionar pautas públicas voltadas para as dores provocadas pelas mais variadas formas de racismo. Para isso, convoca discursos de blogueiras negras, escritas literárias, ensaios, reportagens, palestras TED e entrevistas feitas em seu Programa Espelho ${ }^{23}$, seu declarado lugar de estudo. Além disso, segue com reflexões sobre o sentido carregado por determinadas palavras, como acontece com o verbo resistir, constantemente vinculado aos discursos sobre o racismo. Para o autor e para quem tece esse texto, esse verbo quando relacionado à nossa existência é um paradoxo, se o pensarmos em relação à ideia de uma vida plena, pois resistir pressupõe o constante e o ainda ininterrupto esforço de se fazer firme em espaços nos quais outras pessoas simples ou complexamente vivem (RAMOS, 2017, p. $71,115,121,142,143)$.

\section{A pele que habitamos como leitura literária}

A nossa escrevivência não pode ser lida como histórias para "ninar os da casa grande" e sim para incomodá-los em seus sonos injustos (Conceição Evaristo) ${ }^{24}$

"Escrevivência" é um eufemismo cunhado pela escritora Conceição Evaristo para expressar a escrita que nasce das experiências vividas, da junção de escrever, viver e se ver (EVARISTO, 2017b). Assim, o ato de escrever sobre o vivido está diretamente relacionado às nossas leituras sobre o que vivemos e o que sentimos em relação ao vivido.

É da concepção sobre o ato criativo que envolve o falar sobre si, presente no texto de apresentação de Becos da memória (EVARISTO, 2017a), que partimos: "as histórias são inventadas, mesmo as reais, quando são contadas. Entre o acontecimento e a narração do fato há um espaço em profundidade, é ali que explode a invenção" (s/n). O objetivo da leitura feita neste tópico não é o de questionar a veracidade das escrevivências aqui estudadas, mas de pensá-las também como um espaço no qual figuram os ires e vires temporais acionados pelas memórias de seus protagonistas, que são também narradores e também autores. E aqui se ancora o nosso exercício de uma possível leitura literária. Por, em consonância com a crítica do professor Luiz Costa Lima, acreditarmos no valor fictício de tais narrativas, por suas impossibilidades, mesmo quando involuntárias, de compromisso com a verdade dos fatos, com a fidelidade com o real (LIMA, 2013, p. 365; LIMA, 2014).

\footnotetext{
${ }^{23}$ Exibido no Canal Brasil

24 Texto de apresentação do blog da escritora Conceição Evaristo. Disponível em: http://nossaescrevivencia.blogspot.com.br. Acesso em 19 mar. 2018.
} 
O movimento de olhar em perspectiva para o passado é tratado por Bourdieu (2006), em seu trabalho intitulado $A$ ilusão biográfica, sob o viés de se assumir uma "forma" de escrita autobiográfica, como se tal ponto fosse indissociável de uma concepção de se ter vivido um "conjunto dos acontecimentos de uma existência individual concebida como uma história", de forma a delinear um caminho narrado a partir do encadeamento de uma sucessão de fatos, com exatos começos, etapas, transições e fim, "no duplo sentido, de término e de finalidade", de alcançar um objetivo (BOURDIEU, 2006, p. 183, 184).

Esse contar sobre si, característica das (auto)narrativas vivenciais aqui apresentadas está inserido no em gêneros do chamado "espaço biográfico" (ARFUCH, 2010) e é situado pela autora no período da pós-modernidade, pelo retorno do sujeito e pela dissolução do coletivo, ao passo em que as democracias se consolidavam, abrindo então espaços à "pluralidade de vozes, identidades, sujeitos e subjetividades". Esses registros do acontecer indicam, segundo Arfuch, uma "obsessão por deixar impressões, rastros, inscrições, dessa ênfase na singularidade" (p. 16 - 19).

As narrativas sobre - e por - Ruth, Zezé e Lázaro, têm como estratégias de escrita uma "linguagem simples e direta", no caso das biografias das atrizes, "de maneira coloquial, como se o biografado estivesse falando diretamente ao leitor” (JESUS, 2007, p. 08; MURAT, 2005, p. 06). Por esse motivo, essas mesmas formas de escrita configuradas no supracitado espaço autobiográfico, são confrontadas pelo professor Luiz Costa Lima (2013), pela característica dos relatos, "em linguagem bastante acessível" sobre - e feito por - pessoas sob o spotlight midiático, como nos casos em questão, são chamados de literatura somente por uma questão de publicidade, a "melhor publicidade" que se pode receber, como se fosse um adjetivo e "não há nenhum escrúpulo em fazê-lo" (p. 366). O pertencimento de uma obra não ficcional ao campo literário, segundo sua leitura, estaria condicionado à sua distinção não pelo que é narrado, mas pelo como é narrado, pela linguagem utilizada:

Como não há marcas linguísticas que sejam específicas da literatura, no máximo poder-se-á acrescentar que sua identidade literária decorre do caráter compacto de sua linguagem. Linguagem compacta significa que a configuração verbal de certa obra contém uma densidade de significação tal que faz com que ela, sem se confundir com um quebracabeça, podendo mesmo caracterizar-se pela simplicidade de sua formulação sintática, abranja, se aproxime ou mesmo ultrapasse o arco semântico consignado, na língua em que está composta (LIMA, 2013, p. 366. Grifos do autor).

As (auto)narrativas vivenciais aqui estudadas encontram-se com a metáfora acima utilizada por Lima (2016), por potencialmente poder compor um "quebra-cabeça" de vivências, mesmo que sem compromisso com a linearidade dos fatos, pela escolha do como narrar, adotada por cada autor, tecendo então histórias de forma a parecer que ao passo em que os eventos são narrados, outros acontecimentos são descortinados, nos indicando um movimento no qual o tempo passado da narrativa recorra, por vezes, a outro passado, mais longínquo, que a ele se alia para estrutura-lo ou para elucidar dadas situações.

Nesse percurso de pensar a possível literariedade de obras caracteristicamente não literárias, como no caso das escritas (auto) biográficas em questão e a partir dos citados entendimentos acerca da escolha estilística adotada para cada uma, sigamos pelo ensaio O narrador: considerações sobre a obra de Nikolai Leskov, datado de 1936, de Walter Benjamin (1994). De acordo com o autor, a "arte narrativa" consiste em "evitar explicações" ao leitor, permitindo que o episódio narrado atinja amplitudes imensuráveis no ato da interpretação, pelo estilo subjetivo conferido pela forma como as memórias foram dispostas e enunciados (p. 203). Por mais que possamos interpretar os sentidos e movimentos dentro das narrativas vivenciais de Ruth, Zezé e Lázaro, mesmo o que está nas entrelinhas, suas construções textuais são predominantemente objetivas e, se assim e segundo os teóricos aqui citados, não se constituindo como escritas propriamente literárias. 
Por outro lado, talvez o espaço para pensarmos tais leituras resida na seguinte provocação feita por Lima (2013): "temos, por um lado, a recusa de situar-se a autobiografia como gênero literário, e, por outro, de abordá-la mediante a racionalização positivista" (LIMA, 2013, p. 334). Ainda que as restrições acima organizadas possam impor um limite à proposta de leitura deste trabalho e considerando esse limite como um possível ponto de afastamento do que se entende por literário, nesse terceiro caminho aberto pela leitura do autor, um caminho entre a recusa do reconhecimento de um espaço literário e uma leitura predominantemente positivista, um espaço para o que é criado, pela forma, mesmo que objetiva, pelo espaço de invenção tal como defendido por Evaristo (2017a) e pela escolha narrativa tanto de biógrafos, como nas escritas sobre Ruth de Souza e Zezé Motta, quanto dos (auto)biografados, figurando assim autor-narrador-personagem e seus objetos de enunciação.

Dessa forma, tomemos a seguinte ideia de Lejeune (2014), presente em O pacto autobiográfico, necessária ao nosso entendimento sobre as (auto)narrativas de Ruth (JESUS, 2007), de Zezé (MURAT, 2005) e de Lázaro (RAMOS, 2017): a de que é no nome próprio que se resume "toda a existência do que chamamos de autor. única marca no texto de uma realidade indubitável". Percebamos que o crédito da "realidade indubitável", assim, no singular, não é do autor do relato, mas do "nome próprio" do autor da obra. Essa figura autoral, marcada pelo nome, é a "pessoa que escreve e publica", ao mesmo tempo, uma "pessoa real, socialmente responsável e o produtor de um discurso" (LEJEUNE, 2014, p. 26, 27). O real se finda aqui, no autor.

Em Ruth de Soura: estrela negra (JESUS, 2007), Zezé Motta: muito prazer (MURAT, 2005) e Na minha pele (RAMOS, 2017), temos como realidade as autorias de Maria Angela de Jesus, de Rodrigo Murat e de Lázaro Ramos, mas, no caso das biografias de Ruth e de Zezé, temos também seus nomes como nomes próprios que também pesquisam, selecionam e enunciam suas (auto)narrativas. No caso dessas escritas, diferente da de Lázaro, os biógrafos são também narradores das histórias das atrizes. A poética e objetiva metáfora de Benjamin (1994, p. 205), resume: "a marca do narrador, como a mão do oleiro na argila do vaso".

O corpo que transita nas narrativas (auto)vivenciais seria então um espaço criado, no qual há um eu, que é também seu biógrafo e seu autor, que ali figura, desenhando caminhos e sequências de fatos, de acordo com suas escolhas sobre o que e como contar. É o que Klinger (2008) chama de escrita de si como performance, movimento que simula o narrar como uma representação de seu enunciador, ainda que "mais presente como pessoa do que como performer" (KLINGER, 2008, p. $18 ; 26)$.

O que pressupomos à primeira vista em leituras biográficas e autobiográficas é o seu compromisso com o real; o que percebemos ao nos debruçar sobre tais escritas é a escolha de como ela se dá. Espaço de narração delineado e reconhecendo que as (auto)narrativas aqui estudadas não contemplam todas as especificidades enunciadas por Benjamin (1994) no supracitado ensaio, o que garantiria a elas o status de gênero literário e não uma ideia de sua possibilidade, propomos partir daqui para a abordagem, no próximo tópico, da figura do narrador, por mais familiar e próximo que possa nos parecer, como alguém distante "em sua atualidade viva", justamente pelo espaço da narrativa (BENJAMIN, 1994, p. 197 - 199).

\section{Vozes que se entrecruzam: (auto)narrativas em diálogo}

Para Arfuch (2010), o exercício da (auto)narrativa vivencial como registro de uma história seria como um "passar-se a limpo", forma, na esteira das interpretações sobre as identidades contemporâneas, de singularização de alguém diante das demais vivências, dadas por destaques às narrativas que priorizam as realizações pessoais (ARFUCH, 2010, p. 15,16). Movimento também descrito por Lima (2013), como o de figuras que se forjam, através de seus "autorregistros", de suas especificidades, como diferenciador do outro (LIMA, 2013, p. 332). 
Embora possamos aceitar esse desenho do eu em posição de destaque se em relação ao outro, talvez, o que façamos aqui seja ir justamente por esse lado, para encontrar a diversidade de personagens e histórias, nos negando a contar uma história única ${ }^{25}$, mas também unindo algo que é um ponto de contato entre as três narrativas: a cor da pele como aspecto determinante e de questionamento em muitas das histórias de Ruth, de Zezé e de Lázaro.

O sentido atribuído e carregado pela cor da pele preta é, portanto, o que une as três (auto)narrativas aqui estudadas e que as relaciona com tantas outras do mundo externo, travadas por esse "eu" durante o seu contar sobre si. Podemos inferir que se as narrativas versassem sobre pessoas brancas - e falamos aqui da cor da pele - que tivessem a mesma profissão que nossas personagens, o trabalho permearia um caminho distante deste, porque a adjetivação racial não necessariamente reuniria histórias que, mesmo afastadas temporalmente, foram causa de questionamentos, demarcações de espaços e de papéis. A uma atriz ou ator branco, podemos pressupor que não seriam proferidas perguntas sobre como é fazer um personagem branco; ou sobre os desafios de ser branco; ou sobre ser convidado sempre para fazer o mesmo "tipo" de personagem. Paremos aqui, pois entendemos que essa lista de comparações é extensa.

Durante a composição desse trabalho, nas ações de escrita e reescrita, e, agora durante a leitura, duas palavras salientaram-se: espaço e trânsito. Serão essas as condutoras dos entrecruzamentos feitos a partir desse momento. Assim sendo, o espaço será tomado não somente como o da narrativa, mas também como algo reivindicado, objetivo, tátil, "pisável; o trânsito, necessário à chegada e permanência nos espaços narrados, será lido como um gesto vivido por Ruth, Zezé e Lázaro.

Há uma menina numa casa na qual a mãe lavava roupas quando um homem passou vendendo mangas: "olha aí, criançada, venha ver manga sem caroço", ao que a dona da casa responde: "Aqui não tem criança". Ainda sem entender, ela pensa: "mas eu sou criança"; há uma adolescente, que foi atacada com ovos quando tentou encenar uma Virgem Maria; e há um menino do lado de fora de uma corda de camarote de carnaval, observando um mundo que está ali e é outro. Aqui, todos os relatos são sobre meninas e meninos que cresceram expostos (JESUS, 2007, p.22; MURAT, 2005, p. 26; RAMOS, 2017, p. 26).

Esses são os primeiros preconceitos narrados pelas histórias que compõem o presente trabalho. As cenas prenunciam um movimento que é de negação, de questionamentos e de atuações sobre e para não-apagamentos. A ficção? Talvez resida no espaço de memória enunciado por Evaristo no texto de apresentação de seu Becos da memória (2017a, s/n) e por Arfuch (2010), ao pressupor autocriação nesses atos de registrar afetividades, parte importante da constituição desses sujeitos enunciadores e enunciados (ARFUCH, 2010, p. 68).

Comecemos, então, pelo nome. Para lembrar, o qual resume "toda a existência do que chamamos de autor" (LEJEUNE, 2014, p. 26,27). No caso de Ruth e Zezé, enunciadoras de suas histórias, portanto, produtoras de discursos, mesmo, sabemos, discursos configurados por seus biógrafos. Nome é algo reivindicado por Ruth de Souza e por ela chamado de "luta eterna", ao citar as recorrentes dificuldades de simplesmente - mas complexamente - o ter creditado em seus trabalhos. Essa luta dá-se em razão de um movimento de tentativa de não apagamento pela "confusão" que camufla a transfiguração de tantas histórias em um só corpo, ao já ter sido confundida com outras atrizes, fato lido por Ruth pelo pensamento comum que parece demonstrar que negros são todos iguais.

Essa naturalização, também promovida pela ficção, incontestavelmente ultrapassa seus limites, como acontece quando Ruth é provocada sobre a possibilidade de uma negra ser atriz; quando vinte anos depois, Zezé é provocada sobre a necessidade de fazer curso de teatro para "fazer papel de empregada"; quando, quarenta anos depois de Zezé, setenta depois de Ruth, Lázaro

\footnotetext{
25 Impossível não referenciar a palestra proferida pela autora nigeriana Chimamanda Adichie intitulada "O perigo de uma história única". Disponível em: https://www.youtube.com/watch?v=EC-bh1YARsc. Acesso em 23 out. 2018.
} 
é confundindo com um ladrão ${ }^{26}$ e, desfeita a "confusão", a autora do gesto ter demonstrado não entender o problema em seu ato.

No ano de 2011, a Rede Globo, emissora que produziu as telenovelas citadas pelos enunciadores das (auto)narrativas em questão, passou a inserir o seguinte texto no final dos créditos de sua programação, exceto nos dos programas de auditório: "Esta é uma obra de ficção coletiva baseada na livre criação artística e sem compromisso com a realidade" ${ }^{27}$. A criação artística, mesmo quando tocando em situações cotidianas de conflito, é, portanto, livre. Resolução relativamente recente, mas com questões historicizadas pelas inquietações apresentadas por Ruth, quando cita o outrora proferido "só estamos mostrando a realidade", resposta a seus questionamentos sobre como o negro é retratado nas dramatizações. E continua: "Qual realidade? [...] Novela é ficção" (JESUS, 2007, p. 87 -89). É ficção, mas ultrapassam esses limites quando a cor da pele preta compromete - julga quem as assiste - a verossimilhança da trama.

Tratamos, pois, de cenas que não parecem caber na ficção, como se, de Ruth a Lázaro e antes e agora, continuassem dizendo: essas cores não podem representar isso - protagonista, condessa, cantora senão de samba, galã ou Iago de Orfeu - mas podem representar isso - mulher escravizada, empregada, trombadinha, homem violento ou segurança. Recorro, novamente ao questionamento feito por Ruth:

Nós estamos mostrando a realidade. Qual realidade? Já fizeram mulher que explodia, homem que voou, homem que subiu à Lua. Novela é ficção. Lembra do homem que tinha formiga no nariz? Mas quando se trata do ator negro, começam com essas mesmas desculpas.” (JESUS, 2007, p. 88, 89).

Falamos, portanto, de um espaço passível de negociações, aqui demonstradas em momentos como os em que Zezé abdicou de sua intenção em cantar profissionalmente outros gêneros musicais além do samba, por uma questão mercadológica; e quando Lázaro, no ano de 2007, teve seu projeto para um livro infantil a uma editora recusado ao que a mesma propôs que o ator relatasse sua trajetória como ator negro ${ }^{28}$. Falamos em negociação porque eles indicaram suas leituras sobre esse processo. Zezé acabou gravando discos de samba e estamos aqui tratando justamente da biografia de Lázaro, inicialmente por ele rejeitada.

A distância temporal entre as histórias de cada narrador-personagem talvez seja um indício para localizarmos a maior predominância de recusas advindas de Lázaro e marcadas, como vimos, pelo verbo escolher, como aconteceu com o projeto de sua série Ó paí, ó, que só foi aceito sete anos depois, após sua ascensão profissional (RAMOS, 2017, p. 103).

\section{CONSIDERAÇÕES FINAIS}

Falamos de lugares de memória e de escrevivencias diferentes, mas que, por outro lado, pelos tantos desenhos únicos tecidos também pela dramaturgia brasileira, e sob o qual a cor da pele figura e é, seja em entrevistas, no desenho de personagens ou em suas rejeições, algo que entrecruza essas trajetórias. As histórias, mais distantes ou mais próximas em temporalidade chegam a um tempo no qual é possível admitir que há maior possibilidade de denúncia e, devido aos seus espaços, maior projeção destas, em seus casos, também através das narrativas.

O fato de uma editora propor a Lázaro a escrita de sua história pode até nos indicar uma mudança no cenário da produção cultural em relação ao vivido por Ruth e Zezé, entretanto, isso

\footnotetext{
26 A distância temporal marcada pelo início das carreiras de Ruth e de Zezé em relação à de Lázaro aumentou porque o citado fato ocorreu no ano de 2016.

27 Disponível em: http://redeglobo.globo.com/novidades/noticia/2011/10/rede-globo-exibe-nos-creditos-finaisfrase-que-reforca-o-conceito-de-ficcao.html.

28 Atualmente o autor tem dois livros infanto-juvenis publicados: Caderno de rimas do João; e Caderno sem rimas da Maria, ambos pela editora Pallas.
} 
não anula um ponto que estruturou o presente texto: os questionamentos acerca da sempre presente adjetivação racial. Embora empregada em um contexto diferente do que é aqui desenhado, pego emprestada uma expressão utilizada pelo professor Ítalo Moriconi (2006) para fazer um adendo sobre o livro Na minha pele (RAMOS, 2017), inserido no atual contexto de produção e dos debates mais abertos sobre preconceitos: o possível "valor de fetiche" e, assim, "fato de mercado".

A obra, inserida na atual conjuntura de um crescente mercado editorial relacionado - e alimentado - às demandas sobre a temática étnico-racial, foi lançada na FLIP - Festa Literária Internacional de Paraty - do ano de 2017 e foi a mais vendida de toda a história do evento, mais que o dobro do recorde anterior, segundo somente os dados fornecidos pela Livraria da Travessa, a livraria oficial do evento (BERGAMO, 2017). Segundo a curadora da Festa, é o resultado da influência, sobretudo, dos movimentos feminista e negro e das ações afirmativas "que colocaram negros nas universidades" (AGUIAR, 2017).

O valor desse contar sobre si é situado por Arfuch (2010) como uma característica da prémodernidade num movimento de "deixar impressões, rastros, inscrições", em um horizonte midiático cuja lógica é informativa do "isso aconteceu", como se a experiência narrada fosse, em si, um núcleo de afirmação (p. 15-18). É também, segundo Benjamin (1994), um ato de "dar conselhos", sendo os (auto)narradores "o centro do mundo e em torno do qual gravita toda a história" (p. 210). A isso, somamos a organização dos relatos pelos autores das biografias e da autobiografia aqui estudadas, à seleção do o que e do como narrar, e aqui defendemos a impossibilidade de nos contar em uma retrospectiva tão linear sem que nos separemos do que somos agora, de nossas leituras "a partir de hoje de manhã", como pessoas diferentes das que fomos (CARROL, 2014, p. 139).

Diante dos espaços temporais aqui reunidos, quais são os corpos mais comuns em determinadas narrativas? A seleção de cenas, feita pelo autor de cada obra e também durante a escrita desse trabalho, que é também uma escolha narrativa, aponta para escritas de si que não se distanciam, na vida e diante das câmeras, do que é lido, desenhado e tentado ser imposto em (não) razão da cor da pele. O trânsito, quando acontece, não se dá sem resistência, não sem precisar se confrontar com os muitas vezes ditos-não-ditos.

\section{REFERÊNCIAS}

AGUIAR, Joselia. Joselia Aguiar: "Minha preocupação foi mapear a literatura que está fora dos radares". El País. 17 jul. 2017. Entrevista concedida a André de Oliveira. Disponível em: https://brasil.elpais.com/brasil/2017/07/15/politica/1500072189_755174.html?rel=mas Acesso em 02 jan. 2018.

ARFUCH, Leonor. O espaço biográfico: dilemas da subjetividade contemporânea. Trad. Paloma Vidal. Rio de Janeiro: EdUERJ, 2010.

BENJAMIN, Walter. O narrador: considerações sobre a obra de Nikolai Leskov. In: Magia e técnica, arte e política: ensaios sobre literatura e história da cultura. Trad. Sérgio Paulo Rouanet. 7.ed. São Paulo: Brasiliense, 1994.

BERGAMO, Mônica. Livro de Lázaro Ramos é o mais vendido da história da Flip. Folha de S.Paulo, São Paulo, 07 ago. 2017. Colunistas. disponível em: https://www1.folha.uol.com.br/colunas/monicabergamo/2017/08/1907358-livro-de-lazaroramos-e-o-mais-vendido-da-historia-da-flip.shtml. Acesso em 02 jan. 2018.

BOURDIEU, Pierre. A ilusão biográfica. In: AMADO, J.; FERREIRA, M. M. Usos \& abusos da história oral. 8. ed. Rio de Janeiro: FGV, 2006. 
CARROLL, Lewis. Alice no País das Maravilhas. Porto Alegre: L\&PM, 2014.

EVARISTO, Conceição. Becos da memória. Rio de Janeiro: Pallas, 2017a.

. Conceição Evaristo: 'minha escrita é contaminada pela condição de mulher negra. Nexo Jornal. 26 mai. 2017b. Entrevista concedida a Juliana Domingos de Lima. Disponível em: https://www.nexojornal.com.br/entrevista/2017/05/26/Conceição-Evaristo-'minha-escrita-écontaminada-pela-condição-de-mulher-negra. Acesso em 02 jan. 2018.

JESUS, Maria Angela de. Ruth de Souza: estrela negra. São Paulo: Imprensa Oficial do Estado de São Paulo - Fundação Padre Anchieta, 2007. Disponível em: http://aplauso.imprensaoficial.com.br/edicoes/12.0.812.887/12.0.812.887.pdf. Acesso em 04 jan. 2018.

KLINGER, Diana. Escrita de si como performance. Revista Brasileira de Literatura Comparada, $\quad$ n. $12,2008.20$ Disponível http://www.abralic.org.br/downloads/revistas/1415542249.pdf. Acesso em 22 dez. 2017.

LEJEUNE, Philippe. O pacto autobiográfico: de Rousseau à Internet. Org. Jovita Maria Gerheim Noronha. Trad. Jovita Maria Gerheim Noronha e Maria Inês Guedes. 2. ed. Belo Horizonte: Editora UFMG, 2014.

LIMA, Luiz Costa. Respostas de Luiz Costa Lima. Folha de S. Paulo. São Paulo, 23 fev. 2014. Ilustríssima. Disponível em: http://www1.folha.uol.com.br/ilustrissima/2014/02/1415832respostas-de-luiz-costa-lima.shtml Acesso em 30 dez. 2017.

MORICONI, Ítalo. Circuitos contemporâneos do literário (indicações de pesquisa). Disponível em: www.gragoata.uff.br/index.php/gragoata/article/view/331. Acessado em 05 jan. 2018.

MURAT, Rodrigo. Zezé Motta: muito prazer. São Paulo: Imprensa Oficial do Estado de São Paulo - Fundação Padre Anchieta, 2005. Disponível em: http://livraria.imprensaoficial.com.br/media/ebooks/12.0.813.131.pdf. Acesso em 20 dez. 2017.

RAMOS, Lázaro. Na minha pele. Rio de Janeiro: Objetiva, 2017. 